\title{
Analysis of Egyptian Red Sea Fishing Ports
}

\author{
Mahmoud Sharaan, Abdelazim Negm, Moheb Iskander, and Mohamed El-Tarabily
}

\begin{abstract}
This study aims to present a comprehensive analysis for four cases of Egyptian fishing ports that located on the sensitive environmental area on the Suez Gulf and the Red Sea coasts. The analysis includes the current environmental, planning, and facilities issues. The four investigated ports are the developed, undeveloped artificial fishing ports, natural fishing port, and landing site for fishing practices. The analyzed data are collected from different sources including field survey, visual observation (as a monitoring technique to update the collected data), personal interviews, discussion with the main stakeholders (fishers and administrators) and the available official reports. The current status of these fishing ports is highlighted. The results show that the investigated fishing ports are suffering from increasing of wastes forms with different levels. The findings associated with the catches issues of this sensitive area of the Red Sea and the related fishermen activities are discussed. Also, the results indicate a significant deterioration of the basic infrastructure of natural port and undeveloped artificial ports. A significant variance of the available facilities in the four ports is observed. The recommendation for the future improvements and expansions plans to increase the efficiency of each port are presented.
\end{abstract}

Index Terms - Environmental issues, fishing ports facilities issues, planning issues, red sea.

\section{INTRODUCTION}

Over the years, fish have been considered significant, important, and vital source of world food (protein) [1]. In fisheries, a rise in demand often leads to improper fishing practices and threatening the future of the industry. Without rigorous protection standards, measures, and environmental management, many of the hard-won gains with intentioned planners will be lost [2]. About $90 \%$ of fishing practices that occurs in the coastal waters of the sensitive areas impacts on the coral reef and its degradation [3]. Recently, coral reefs have come under severe threat due to illegal fishing, the drainage of untreated sewage, toxic wastes of shipping including and increased shipping activities carrying chemicals and crude oil.

The Red Sea is a deep semi-enclosed basin connected to the Indian Ocean by a narrow sill in the south (Mandeb Strait) and to the Suez Canal in the north. The Northern Red Sea is

Manuscript received February 14, 2016; revised March 30, 2016. The work was supported by Mission Department, Egyptian Ministry of Higher Education (MOHE), Egypt-Japan University of Science and Technology (E-JUST), and partially supported by Coastal Research Institute, National Water Research Center, Ministry of Water Resources and Irrigation, Egypt.

Mahmoud Sharaan, Abdelazim Negm, and Mohamed El-Tarabily are with the Environmental Engineering Department, School of Energy and Environmental Engineering, Egypt-Japan University of Science and Technology, Alexandria, Egypt (e-mail: Mahmoud.Sharaan@ejust.edu.eg, Negm@ejust.edu.eg, Mohamed.eltarabily@ejust.edu.eg ).

Moheb Iskander is with Coastal Research Institute, Egypt (e-mail: Coastal_alex@yahoo.com). an important sea area both for fishing and for its unique and often spectacular marine environment as coral reefs, mangroves and seagrass beds [4]. Also, Red Sea tourism is largely dependent on the surrounding environment especially coral reefs, which are sensitive to tourist activity. The delicate area of the Red Sea coast of Egypt contains about $66 \%$ of hard coral reefs species existing within the Red Sea including some endemic species [5] Also; coral reefs provide protection and shelter natural zone for many different species of fish. The coral reefs are affected by destructive fishing, overfishing, marine-based pollution, coastal development, and pollution. Overfishing classified as the major local threat affecting $55 \%$ of the world's reefs, through an increase in commercial fishing and heavy trawling [6]. Also, some types of fishing gear, including gillnets and beach seines, can also damage reef ecosystems.

The fact that the Red Sea bordered by eight countries and its slow rate of water turnover contribute to increasing the pollution issues in the Red Sea [7]. Therefore, many of the exploited fish stocks (particularly the large and small pelagic species) in Egypt are shared with neighboring countries [4]. Fish production rates in the Red Sea have decreased during the past 20 years because of environmental pollution, which caused the loss of up to 70 percent of its fishing wealth [8]. In addition to, the annual growing of population increases the pressure on fisheries due to increased demand for fish.

Furthermore, the Red Sea-Suez Canal pathway is one of the most important international marine pathways with highly intensive ship traffic. Some of these vessels are running by nuclear power or carrying radioactive materials, which is a source of possible accidental contamination [9]. Oil industries at the Gulf of Suez, phosphate ore mining activities in Safaga - Quseir region and intensified navigation activities are considered non-nuclear pollution sources [10], [11]. According to the United Nations Environmental program (UNEP), the major threats to the marine environment of the Red Sea proper and the Gulf of Aden are related to land-based activities, these include urbanization and coastal development [12].

The role of the fishing port may consider as the interface connecting the harvesting of the fish stocks and its consumption. The type and size of a fishing port and its essential infrastructure considerably influence the way and the rate at which a country's living coastal resources can be exploited [13], [14]. The factors which affect the health and safety of deep-sea fishermen are several and varied such as design, construction, and stability of the vessel and its equipment. Selection and training of the crew, their health surveillance, methods, and hours of work, and personal protection are additional factors. Also, special services at seas such as weather forecasting and medical and technical aid are provided by support ships [15]. 
In Egypt, the fishery sector considers one of the important sectors in the economic structure of the country [16]. The fishery serves vast regions of more than 13 million acres that differ according to the type of these sources, such as coastal (Mediterranean and the Red Sea), inland (lakes and Nile River) and aquaculture. There are 21 Egyptian natural and artificial marine fishing ports and bays located at each of Mediterranean, Red Sea coasts and lakes. Only five of these marine fishing ports have the minimum requirements of infrastructures, facilities, and equipment for catches, (Port Said, New El-Burullus, and Elmaadiya at the Mediterranean, as well as Attaka, and Hurghada at the Red Sea) [17]. On the other hand, marine fisheries have a classical history in Egypt, but their importance has decreased about freshwater fisheries and aquaculture, with the latter accounting for $74 \%$ of total fish production in Egypt in 2012 [18].

Fisheries legislation in Egypt based on a 1983 Decree, which provides the administrative basis for fisheries management. However, the legislation is inadequate in providing a basis for effective management of fishing in Egypt. Also, enforcement of the few laws is weak and, as a result, fisheries are essentially unregulated. "Effective management is also hampered by the general lack of adequate assessments of major commercial fish stocks and by the complexities inherent in the shared nature of many of these stocks" [4]. The most important common fishing gear types in the Egyptian fisheries are trawl net, purse seine, longlines, and fixed nets. In 1992, the national government issued a decision that prohibited additional granting licenses for trawling in both the Red Sea and Mediterranean due to the continued growth of the fishing fleet [19].

This research aims to spotlight the current status of the existing artificial and natural fishing ports located on the sensitive environmental zone of the Red Sea coast of Egypt. Four cases investigated by visual observation, field visit, and discussion with the main stakeholders to present the characterization of the fishing ports and fishermen activities. The current environmental issues, planning, and facilities issues for the investigated ports are presented. As well as the recommendation for the future improvements and expansion plans to increase the efficiency of each port are presented.

\section{ThE STUdy AREA}

The Egyptian shorelines extend 3,000 Km along each of the Mediterranean and the Red Sea coastal. The Red Sea encompasses two gulfs, the Gulf of Suez and the Gulf of Aqaba, in addition to the Red Sea proper. The Gulf of Suez is bordered by Egypt entirely, while the boundaries of the Gulf of Aqaba shared among four countries: Egypt, Israel, Jordan, and Saudi Arabia. Six countries border the Red Sea proper: Egypt, Sudan, Eritrea, and Djibouti on the western shore and Saudi Arabia and Yemen on the eastern shore [20].

Marine fisheries are less importance to Egypt than its major freshwater fisheries and aquaculture industries and represent only about $8.32 \%$ and $7.37 \%$ of the total fish production in Egypt at years 2012 and 2013 respectively. Approximately $40.9 \%$ of the total marine fish catch comes from the Red Sea and Gulf of Suez, with the remainder coming from the Mediterranean coast according to (GAFRD fish statistics yearbook 2014) [21]. Also, the annual fish production decreased by $6.60 \%$ in 2013 compared with 2012 along the Red Sea only.

Four of Egyptian fishing ports that are located on the Egyptian Red Sea selected as a study area, (Attaka, Salakhana, Hurghada, and El-Tor). Fig. 1 presents the visited Egyptian fishing ports that located on Red Sea coast of Egypt. In term of fisheries, the most important fishing area in the Egyptian Red Sea is the Gulf of Suez. Attaka is considered the most developed artificial fishing port in Egypt and Hurghada is deemed artificial fishing port but with less developed infrastructure. While, Salakhana is regarded as one of the oldest natural fishing port at the Egyptian Red Sea. Furthermore, El-Tor is considered to be a natural fishing port, but it acts as a landing site for fishing practices only.

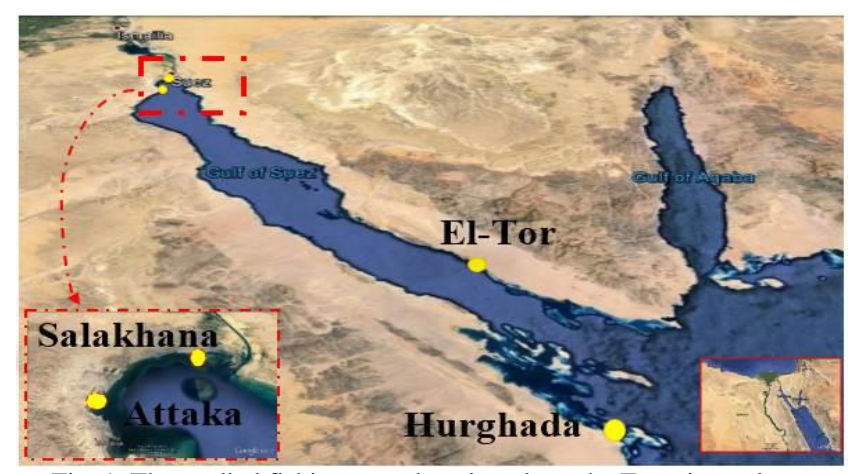

Fig. 1. The studied fishing ports location along the Egyptian red sea.

\section{MATERIAL AND METHODS}

The study was performed using different measures for collecting data. Official reports and database issued by GAFRD [18], and on-site observations are the main sources of data for this study. An extensive search for more data about ports of the Egyptian Red Sea is conducted where data gaps were identified. The knowledge of people (fishers and administrators) who are familiar with different issues is collected via personal interviews, and discussion to fill in gaps, interpret data and the results of our analysis. Also, both the discussions and the personal interviews, the monitoring via visual observational tool are considered one of the certain data collection methods identified with qualitative research, [22]. Observation grants the opportunity to record, analyze behavior and interactions as they occur as well as satisfy the quality assurance of the collected data.

The questions directed to fishers through the discussion and the interviews concerned about the environmental issues, pollution causes, impacts, sedimentation issues, and catches issues. As well as port master plan, and facilities issues such as water area suitability, efficient maneuvering, breakwater alignment, berths, drafts, stores, marketing, and fishing equipment. Moreover, the role of the administration towards the fishermen issues and satisfaction of the fishermen are discussed. Also, the recommendations for the future improvements and expansions to increase the efficiency of each port are presented. Through the field visit, some of the photos are collected to describe the status within some of the fishing ports. The following steps are used to collect the needed data for this study. 
1) The database and reports published by GAFRD are collected.

2) Field trips are planned and conducted for the investigated ports for visual observation and monitoring.

3) Conducting group discussions with the fisher's crew and knowledge people about the different issues within the investigated fishing ports.

4) Implementing the personal interviews with the managers of the fishing ports.

\section{RESUlTS AND DisCUSSION}

The discussions are conducted and recorded by the first author with 7 to 8 of fisher's crews and knowledge of people who are familiar with the fishing practices. The average fishing boat crew is six fishermen at Hurghada, El-Tor, and Salakhana fishing ports, while it is 12 fishermen at Attaka fishing port. The personal interviews are implemented with at least 2 of the port managers in each of the investigated fishing ports. The collected data by visual observation, recorded discussions, and personal interviews are analyzed. The analysis of the finding results is categorized into environmental, port planning, and facilities issues. Environmental issues are presented cumulatively for the four cases because it contains the similar issues, causes, and impacts. On the other hand, the outcome results of the fishing ports planning and facilities issues are individually presented. Also, the comments and discussion results of the fishermen concerning the quality of the available facilities and services are presented. Furthermore, the comments collected from port managers about mentioned issues and for future improvements are presented.

\section{A. Environmental Issues}

The results of the discussions and the personal interviews with the knowledge people support the condition issued by GAFRD statistics that there is a clear fluctuation of the fish stocks within the Red Sea. Fig. 2 indicates the annual fish production of the Red Sea from year 2004 to 2013. Moreover the results of the discussion refer to exiting loss of some varieties of fish. The fishermen believe that fish stocks decreased due to the increasing of pollution levels within the Red Sea. Also, some of the fishers are catching illegally even within or outside the regional water area despite facing possible risks such as losing licenses, fines, and going to prison. Also, some of the fishermen changed their fishing craft to trawl although their license is longlines.

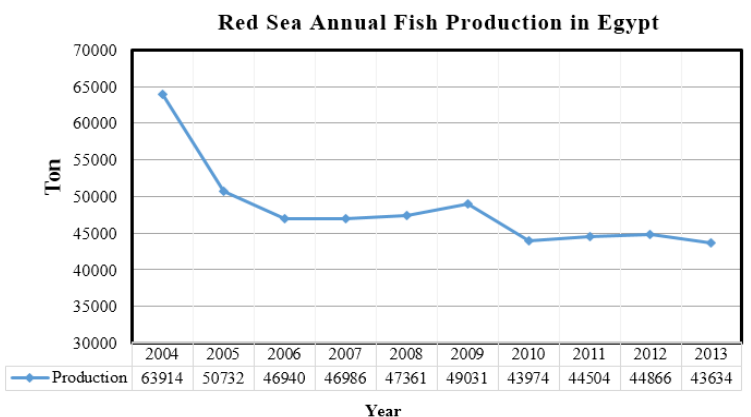

Fig. 2. Shows the annual red sea fish production from year 2004 to 2013.
The results of interviews and visual observation refer to spread of different solid and liquid wastes within the investigated fishing ports with different levels and forms of pollutants. It is observed that the artificial fishing ports (Attaka and Hurghada), and landing site of El-Tor have a lower level of wastes compared to natural fishing port (Salakhana). Although Attaka fishing port has applied measures for collecting various wastes, there are various pollutants forms especially at the zone of boat maintenance (spillway). Fig. 3(a) and 3(b) show the extent wastes forms in Salakhana and Attaka fishing ports.

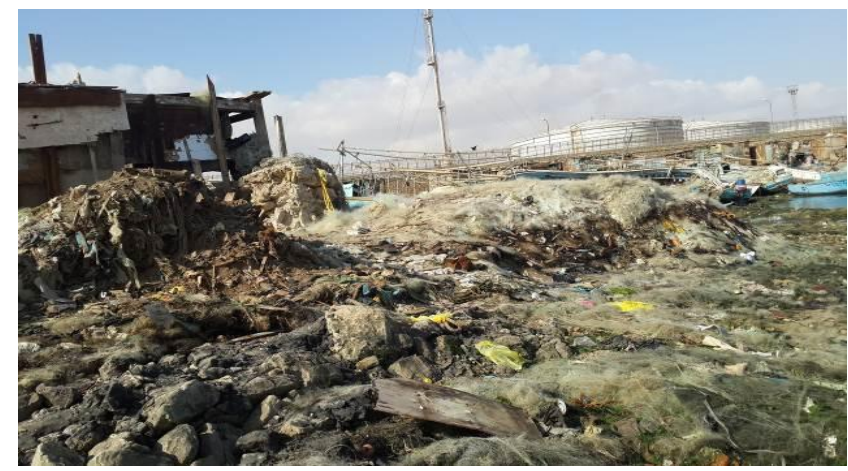

Fig. 3(a). The extent of wastes forms in Salakhana.

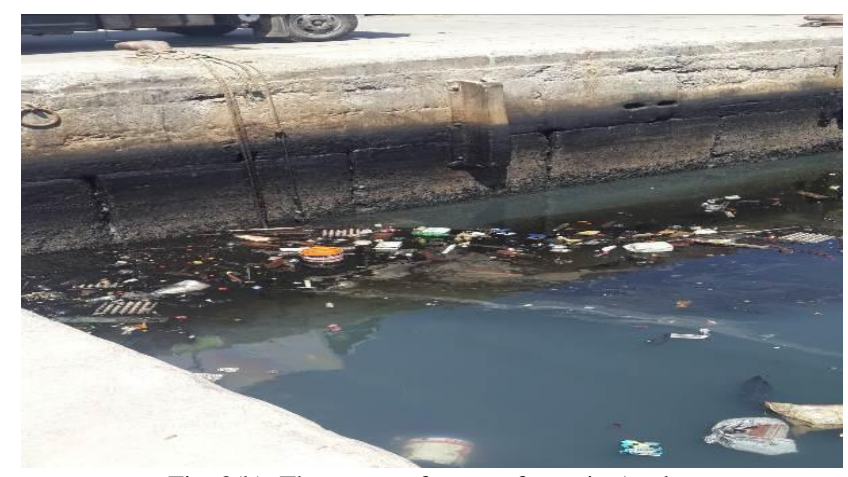

Fig. 3(b). The extent of wastes forms in Attaka.

Regarding sedimentation issues, the fishermen at different studied fishing ports confirmed that the fishing ports on the Red Sea are not suffering from erosion or sedimentation problems. Only some of the solid wastes accumulate within the harbor area.

Coral reefs are highly diverse, valuable critical marine ecosystems that are increasingly threatened by overexploitation [6]. The fishermen confirmed that the coral reefs do not pose a threat to the fishermen life or fishing vessels. Coral reefs places are well known for all fishermen, they use Global Positioning System (GPS) for identification the position of the coral reefs. Nevertheless, the illegal fishing and overfishing pose a threat to the coral reefs. Also, the fishermen commented that the fishing nets and seines can be deteriorated during catching practices near to the coral reefs, although, the environmental laws prohibit fishing practices around the reef zones. Furthermore, there are buoys within the Red Sea, but some of the fishermen prefer to rest at reef's back to avoid storms despite facing possible risks like boat damage.

GAFRD applies some rules, decrees and laws to reach the maximum sustainable yields (MSY) and manage the marine fisheries as prohibiting the fishing within a specific period of 
the year and for specific crafts. For example, the GAFRD issued a closed season for trawling craft from 1 June to 30 September each year, placing a freeze on the issue of additional trawl licenses, and prohibiting two months for longlines. Nevertheless, some of the fishermen are not commitment with the prohibited periods. The fishermen commented about the fishing prohibited periods and how this prohibition affects their livelihood. They believe that the financial compensations are not suitable or equitable for the fishermen.

On the other hand. The fishermen are satisfied with the applied measures to keep the port environmentally and healthy at Attaka fishing port and the landing site of El-Tor. While, the fishermen are not satisfied with the administration efforts and role within Hurghada fishing port. Salakhana fishing port is considered one of the oldest natural fishing area at Suez Gulf and the port is suffering from a complete absence of the administration role in different issues. In addition, some of the fishing boats and fishing nets are affected by oil spill issues.

\section{B. Planning and Facilities Issues}

\section{1) Attaka fishing port}

Port Description. Attaka fishing port located $20 \mathrm{~km}$ south of Suez city on the Egyptian Suez Gulf. The port was constructed in 1992, and the actual operation was in 1995. The port is considered one of the most developed artificial fishing ports in Egypt. The port capacity is about 1500 fishing vessels vary according to its craft such as longlines, bottom trawl fishing, and purse seine. The port contains two berths with a total length of $932.4 \mathrm{~m}$ and the depth within the port ranges from 2 to $5.0 \mathrm{~m}$. The land area is about 170,000 $\mathrm{m}^{2}$, and the port is supplied by different facilities for fishermen and fishing vessels. Fig. 4 shows the alignment of Attaka fishing port.

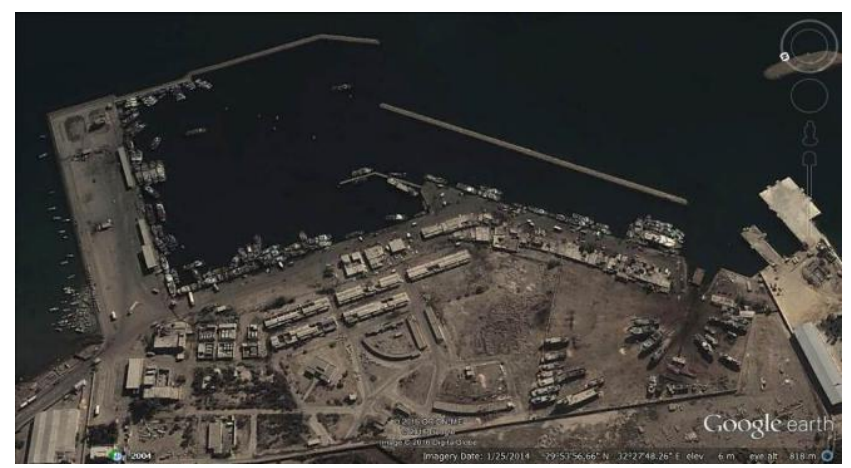

Fig. 4. The alignment of Attaka fishing port.

Attaka Planning and Facilities Issues. The results of the interviews and discussion with the fishermen indicated that the fishermen are satisfied with water and land areas alignment. In addition, the port is well connected with the main transportation roads. The fishermen are not suffering from any problems during their maneuvering within the port. It should be mention that the tidal range is about $1.7 \mathrm{~m}$ in normal values while the maximum recorded value was $2.4 \mathrm{~m}$; the fishermen commented that the berths are well designed to adapt to the variation of the tide. Fig. 5 shows the actual water level in the port during the normal value of tide. On the other hand, all facilities for fishermen and fishing vessels are developed. That includes each of sheds, stores, auction building, water tanks, fuel station, ice factories, environmental protection measures and slipway for maintenance. Moreover, the administration office is existing within the port.

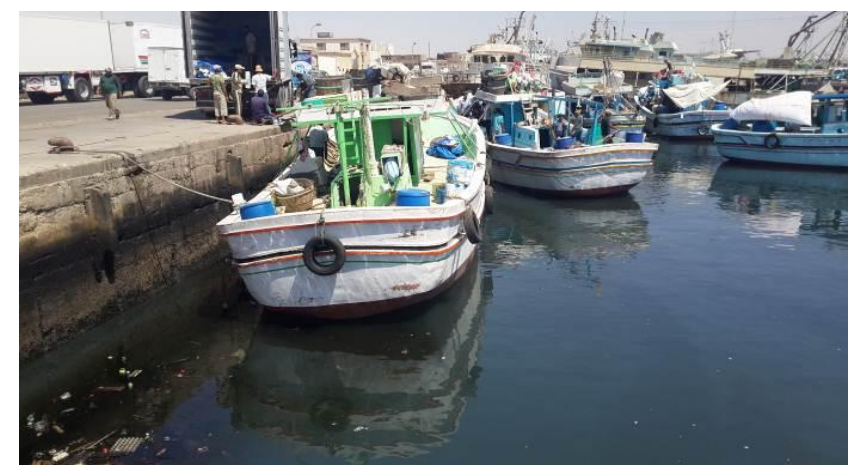

Fig. 5. Actual water level within the port during the low tide.

Future Improvements. The managers of Attaka fishing port have the plan to upgrade and modify some of the existing facilities and construction. For example, they plan to construct a new communication center for contacting and tracking of fishing vessels, a fire station within the port to increase the safety procedures, and increase the number of fishermen's stores within the port. Furthermore, the GAFRD plan to increase the coastguard members for actual monitoring for fishermen's illegal practices.

\section{2) Salakhana fishing port}

Port Description. Salakhana fishing port is located in the south of Suez city on the Egyptian Suez Gulf. The port is considered one of the oldest natural fishing ports on the Red Sea coast of Egypt. The port capacity is about 300 fishing boats, and it was observed that there is a clear variance between the fishing fleet within Attaka and Salakhana, where Salakhana port receives different undeveloped fishing boats, their drafts are ranged from 0.6 to $1.0 \mathrm{~m}$, and it does not exceed $1.5 \mathrm{~m}$. The popular fishing craft is longlines, trawl fishing, artisanal, and recreational. The fishermen's catches license at Salakhana port is limited to Ras-Ghreb zone (near the southern part of Suez Gulf). Fig. 6 shows the alignment of Salakhana fishing port. The port without berths and the fishermen berth the fishing boats irregularly within the water area and behind an existing longitudinal barrier (west barrier of petrol port)

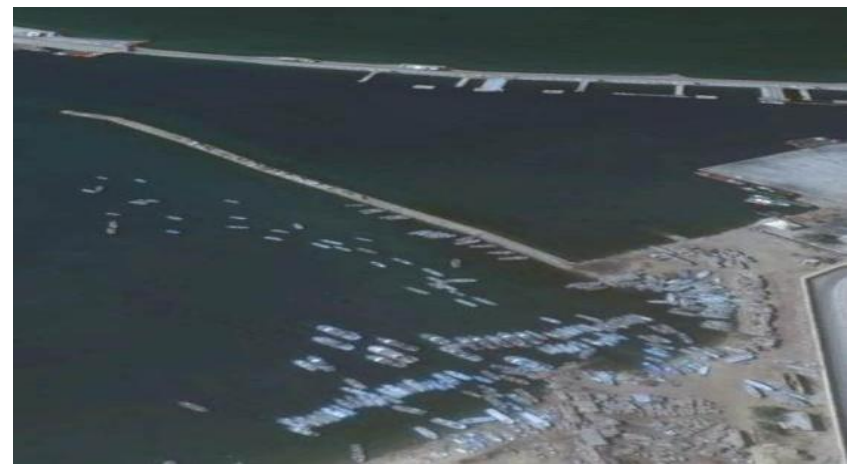

Fig. 6. Salakhana fishing port.

Salakhana Planning and Facilities issues. The port lacks 
the basic infrastructure. The port is suffering from deterioration of the land area, in addition to the spread of old wood stores through the unplanned land area. Moreover, the fishermen use a traditional measure for berthing and mooring their fishing boats at the shoreline. Some of the fishermen ask the petrol port to use their basin, especially during storms. Fig 7 shows the berthing fishing boats at Salakhana fishing port. It should be mention that the fishermen are suffering to arrive at their fishing boats due to tidal ranges effect, where the fishing boats are resting away from the shoreline.

Furthermore, there is a clear absence of the necessary facilities for fishing and fishing boats. There is no fuel station, ice factories, electricity network, or environmental protection measures. Only, an outlet for clean water exists within the port. The fishermen depended upon their personal efforts for supplying each of fuel, oil, and ice. They use nearly existing slipway for maintenance. The fishermen are not satisfied with the role of the administration. They commented that the role of GAFRD was limited for fish statistics and monitoring the auctions, which conducted at the shoreline.

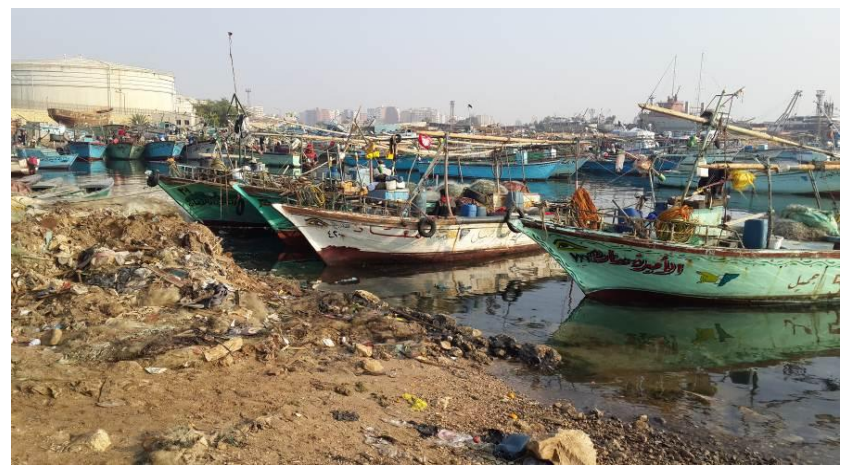

Fig. 7. The berthing fishing boats at Salakhana fishing port.

Future Improvements. The General Authority for Fish Resources Development has a plan to upgrade and increase facilities to improve the status of the port. Fig. 8 shows the boundary of the new plan for the port which includes berths and facilities to improve the port efficiency. The total area of expansion is $21,226 \mathrm{~m}^{2}$.

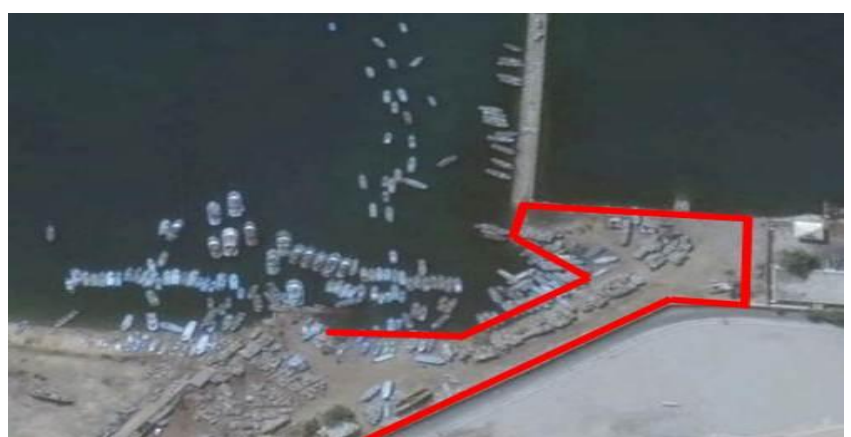

Fig. 8. The boundary area of the plan for the new Salakhana port.

\section{3) Hurghada fishing port}

Port Description. Hurghada fishing port is located on the Red Sea coast of Egypt. The port was constructed in 1991. The port capacity is about 240 fishing boats, about $50 \%$ of the port capacity can berth within the port basin while the others are mooring in the water area outside the basin. On the other hand, most of the fishing crafts are longlines, artisanal, and variety of gears used by the traditional subsistence fishery. The port contains two berths with a $150 \mathrm{~m}$ length each, and the depth of the port ranges from 0.7 to $2.0 \mathrm{~m}$. The total area is about $6,000 \mathrm{~m}^{2}$, and the port has limited facilities for fishermen and fishing boats. Fig. 9 shows the alignment of Hurghada fishing port.

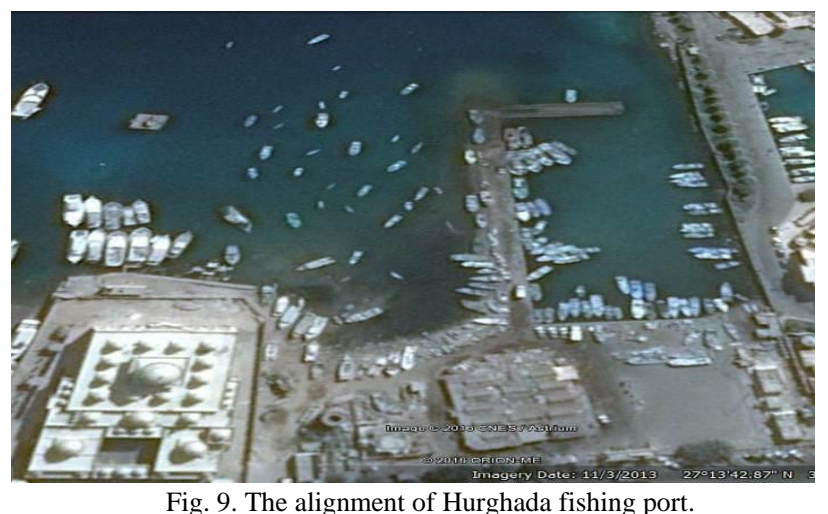

Hurghada Planning and Facilities Issues. The results of the interviews and discussion with the fishermen indicated that the fishermen are not satisfied with water and land areas alignment. The fishermen believed that the water area is not suitable in addition to the delicate maneuvering within the basin as well as the entrance is very narrow. Although there are available land area but the administration are not exploited it efficiently. Despite the small tidal range (about $0.2 \mathrm{~m}$ to $0.5 \mathrm{~m}$ in average) the sea water floods over the berth deck level during the high tide. Fig. 10(a) and 10(b) show berth deck level during the low and high tide.

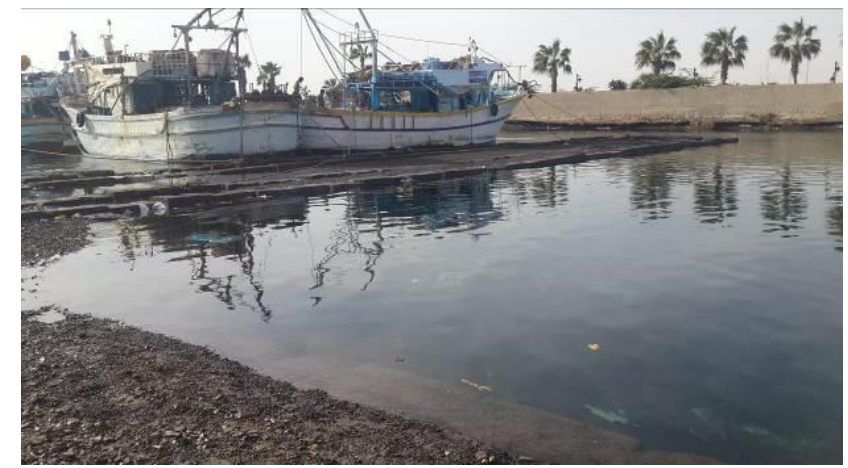

Fig. 10(a). The berth deck level at Hurghada fishing port during low tide.

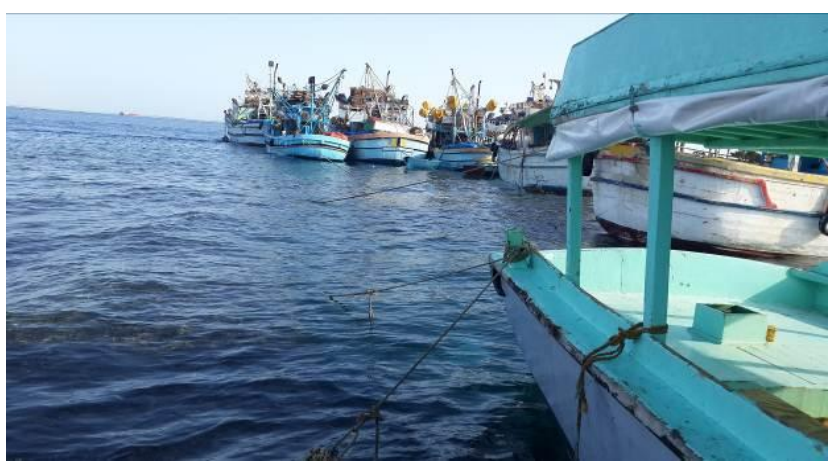

Fig. 10(b). The berth deck level at Hurghada fishing port during high tide.

Regarding offered facilities, the fishermen are not satisfied with the offered facilities for fishermen and fishing boats. The port lacks main facilities such as fuel station, ice 
factories, environmental protection measures and actions of maintenance. The fishermen depended upon their personal effort. In addition, there are a limited number of old wood stores and local auction markets.

Future Improvements. The managers of Hurghada fishing port announcement that, the Hurghada fishing port is included in the Egyptian government plan to develop the port They mentioned that the current basin would be developed by increasing the water depth, the deck level, and the berth length. The berth length will extend by $16.0 \mathrm{~m}$ at the first stage. On the other hand, the managers commented that the development will include upgrade and modify some of an existing facilities as well as supply new facilities. For example, the fishing markets and auction stores will reconstruct, as well as construct a new fire station, fuel station, ice factory, environmental protection measure, upgrading the electricity network and construct the administration building. Also, the development will include preparing a particular land area for maintenance.

\section{4) El-Tor fishing port}

Port Description. El-Tor fishing port is located on the Red Sea coast of Egypt at Sinai South zone. The port is considered one of the natural fishing ports in Egypt and it act as the main landing site for fishing vessels. The port capacity is about 77 fishing boats, most of the fishing crafts are longlines, and artisanal. There are a variety of gears used by the traditional subsistence fishery resting at the west of the port. Furthermore, the port receives three fishing vessels of trawl craft every day for unloading their stocks, and these vessels leave the port just after unloading. The port contains one berth $76 \mathrm{~m}$ length, and the depth of the port is about to 4.0 $\mathrm{m}$. The land area is $12,600 \mathrm{~m}^{2}$ while the water area is 25,200 $\mathrm{m}^{2}$. The port has limited facilities for fishermen and fishing boats. Fig. 11 shows the alignment of El-Tor fishing port.

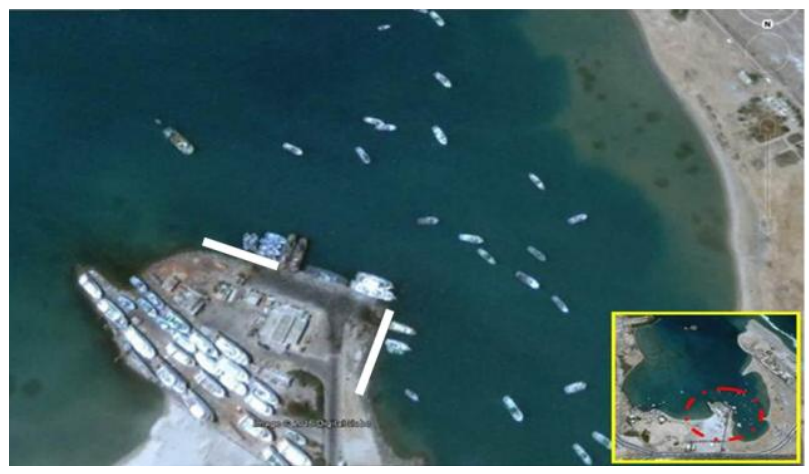

Fig. 11. El-Tor fishing port

El-Tor Planning and Facilities Issues. The results of the interviews and discussion with the fishermen indicated that the fishermen have no issues with the water area or maneuvering within the port because it is an open naturally sheltered area. In addition, the port is well connected with the main transportation roads. Despite, the small tidal range (about $0.3 \mathrm{~m}$ in normal values and $1.0 \mathrm{~m}$ maximum), the fishermen of small boats cannot berth within the low tide. Regarding facilities, there are offered facilities such as fire station, fuel station, water tanks, electricity network, sheds, stores and environmental protection measure. As well as existing of maintenance workshop about meters from the port.
All catches transported to Suez city factories and markets, so there is no need to auction building at the port. It should be mention that there is an administration office within the port, and the fishermen are satisfied with the manager's role.

Future Improvements. The managers of El-Tor fishing port mentioned that the future improvement will include construction a new longitudinal berth as an extension for the existing by $50 \mathrm{~m}$ length. As well as another berth perpendicular to the current berth to the south for berthing of small boats, (white color lines in the figure refer to the position of new berths). Additional stores will be built as well as ice factory.

\section{CONCLUSION}

Studying the Egyptian fishing ports is considered the first stage towards raising the efficiency of the fishing industry in Egypt as a part of the Egyptian government plan. Four of the Egyptian fishing ports that are located within the sensitive environmental area on the Red Sea coast were selected for the present study. These ports include developed (Attaka), undeveloped artificial ports (Hurghada), natural port (Salakhana), and landing site (El-Tor). The needed data were collected from a variety of sources including official statistical reports of fishery data, discussion with the main stakeholder and personal interviews, as well as site observation, field visits and related published materials.

The results show that the fishing ports (located on the Red Sea) are suffering from many environmental, planning and facilities issues. Through the investigated fishing ports, the spread of solid and liquid wastes forms are a common environmental issue, while the degradation of fish resources and corresponding fishermen activities are the common catches issues. It is observed that there are no erosion or sedimentation problems within the investigated ports.

Regarding planning and facilities, each of the studied fishing ports has a unique characterization. Attaka fishing port is the most organized, well planned and developed port. In contrast, Hurghada port is seen as unorganized, and suffering from deterioration of the essential infrastructure, in addition to limited offered facilities. While, Salakhana port is suffering from a complete absence of the basic infrastructure and lack of the main required facilities. On the other hand, El-Tor fishing port is well planned and organized landing site as well as it has different facilities despite its limited land area. Furthermore, the future recommended improvements and expansions plans to increase the efficiency of each port have been presented.

\section{ACKNOWLEDGMENT}

The author would like to thank Egyptian Ministry of Higher Education (MOHE) for providing the financial support (Ph.D. scholarship) for this research as well as the Egypt-Japan University of Science and Technology (E-JUST) for offering the facility and tools needed to conduct this work. Also, many thanks to the fishermen and managers of the fishing ports for their cooperation and discussions during the field visits. Many thanks are due to the Coastal Research Institute, National Water Research Center, Ministry of Water 
Resources and Irrigation, Egypt for their kind cooperation.

\section{REFERENCES}

[1] H. Ligteringen and H. Velsink. Ports and Terminals. [Online] Available: http://www.vssd.nl/hlf/f031.htm

[2] International Navigation Association, PIANC, "Planning of fishing ports," Report of Working Group, vol. 97, 1998.

[3] E. Bollmann, "Living with the oceans," World Ocean Rev. Maribus gGmbH, Pickhuben 2, vol. 1, p. 236, 2010.

[4] F. A. O. Fisheries and T. Paper, Review of the State of World Marine Capture Fisheries Management: Indian Ocean, FAO Fisheries Technical Paper, 2006.

[5] Persga, The Status of Coral Reefs in the Red Sea and Gulf of Aden: 2009, PERSGA Technical Series Number 16, PERSGA, Jeddah, 2010

[6] D. Bryant et. al., Reefs at Risk Revisited, Technical Report, 2011.

[7] G. Wilson, A. R. G. Price, T. Huntington, and S. C. Wilson, "Environmental status of Yemen's gulf of aden coast determined from rapid field assessment and satellite imagery," Aquat. Ecosyst. Heal. Manag., vol. 6, no. 2, pp. 119-129, 2003.

[8] Red Sea shore loses up to $70 \%$ of its fish stock to pollution. Arab News. [Online]. Available: http://www.arabnews.com/news/461752

[9] J. P. Hawkins and C. M. Roberts, "The growth of coastal tourism in the Red Sea: present and possible future effects on coral reefs," Biol. Conserv., vol. 76, no. 2, pp. 216, 1996.

[10] M. H. El Mamoney and A. E. M. Khater, "Environmental characterization and radio-ecological impacts of non-nuclear industries on the Red Sea coast," J. Environ. Radioact., vol. 73, no. 2, pp. $151-168,2004$

[11] W. Gladstone, N. Tawfiq, D. Nasr, I. Andersen, C. Cheung, H Drammeh, F. Krupp, and S. Lintner, "Sustainable use of renewable resources and conservation in the red sea and gulf of aden: Issues, needs and strategic actions," Ocean Coast. Manag., vol. 42, no. 8, pp. 671-697, 1999

[12] Egypt must go green to save red sea | joseph mayton | opinion | the guardian. [Online]. Available: http://www.theguardian.com/commentisfree/2010/oct/14/egypt-red-se a-pollution

[13] J. A. Sciortino, Fishing Harbour Planning, Construction and Management, Rome: Food and Agriculture Organization of the United Nations, 2010.

[14] D. C. Israel, R. Marie, and G. R. Roque, "Analysis of fishing ports in the Philippines," 2000

[15] R. S. F. Schilling, "Hazards of deep-sea fishing1," pp. 27-35, 1971.

[16] F. A. Seham and A. M. Salem, "The present status of fishery and information system in Egypt," MedFisis Technical Document, 2004

[17] Fishing ports - Maritime transport sector. [Online]. Available: http://www.mts.gov.eg/en/sections/15

[18] General authority for fish resources development. [Online]. Available: http://www.gafrd.org/

[19] Socio - Economic analysis of e gyptian fisheries: Options for improvement," 2014.

[20] G. A. Mustafa, A. Abd-Elgawad, A. M. Abdel-Haleem, and R. Siam, "Egypt's red sea coast: Phylogenetic analysis of cultured microbia consortia in industrialized sites.," Front. Microbiol., vol. 5, no. August, pp. 363, 2014.

[21] Articles about fish statistics - General authority for fish resources development official website. [Online]. Available: http://www.gafrd.org/topics/151983

[22] J. Lewis and J. Ritchie, "Qualitative research practice: A guide for social science students and researchers," p. 349, 2003.

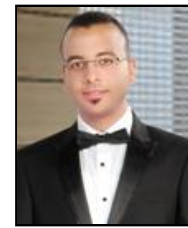

Mahmoud Sharaan was born in 1984 at Port-Said, Egypt. $\mathrm{He}$ has got his bachelor of science degree in civil engineering, Faculty of Engineering, Suez Canal University, Port-Said in 2006. Mahmoud's master degree of science was hydraulic engineering from Civil Engineering Dept., Faculty of Engineering, Port-Said University, Port-Said in 2011. Now, he is a Ph.D. student at Egypt-Japan University of Science and Technology, (E-JUST). He worked as a demonstrator at Civil Engineering Department, Faculty of Engineering, Suez Canal University, Ismailia, Egypt from 2006 to 2011. From 2011 till now, he has been an assistant lecturer at the Water Resources Department, Faculty of Engineering, Suez Canal University, Ismailia, Egypt.

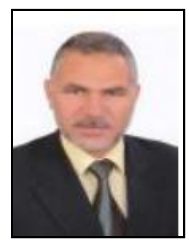

Abdelazim Negm was born in Sharkia, Egypt. His background is civil engineering because he was graduated from Irrigation and Environmental Engineering Dept. in 1985. Prof. Negm has got his M.Sc. degree from Ain Shams University in 1990 in hydrology of the Nile basin. He got the PhD degree in 1990 in hydraulics. Currently, he is a professor of water resources in Egypt-Japan University for Science and Technology (E-JUST) since Oct. 2012 and chairman of the Environmental Engineering Dept. at E-JUST since Feb. 17, 2013. He worked as a demonstrator in Faculty of Engineering, Zagazig University in 1986 and continued till he occupied the position of vice dean for Academic and Student Affair. He was promoted as a professor of hydraulics. His research areas are wide to include hydraulic, hydrology and water resources. He published about 280 papers in national and international journals and conferences. He is listed in (a) Marquis Who is Who?, (b) IBC's 2000 Outstanding Intellectuals of the 21st Century, and (c) ABI directory for his achievement in the field of Hydraulics and Water Resources. He participated in more than 55 conferences. He has awarded the prizes of bes papers three times. He participates in the two EU funded international projects. For his detailed information one can visit his websites www.amneg.name.eg and www.amnegm.com.

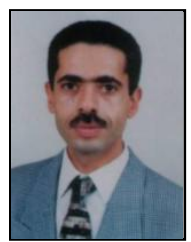

Moheb M. Iskander is an associated professor, the head of Hydrodynamic Department, Coastal Research Institute, National Water Research Center, Alexandria, Egypt. He has got his B.Sc. degree in civil engineering in 1993 and $\mathrm{PhD}$ degree in 2005 in coastal engineering from Alexandria University. He has the following professional experience: Sharing in many of the CoRI projects in studying coastal processes, some field activities, proposing problem solving by using mathematical models, coastal structure designing and participating in reports writing modified 2D numerical model (ImSedTran-2D model) for wave distribution and coastal sediment transport with a special module for coral reef from 2002 to 2005

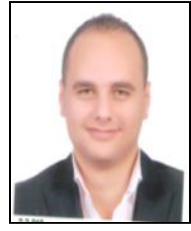

Mohamed El-Tarabily was born in Port Said, Egypt on 29 November 1987 and has been graduated in May 2009 from Suez Canal University, Port Said, Egypt and was awarded the B.Sc. degree in "Civil Engineering" with average appreciation "Excellent with honors degree $85.69 \%$ " with graduation project appreciation "Excellent" and was Awarded the degree of Master of Science (M.Sc.) in civil engineering (irrigation and water resources).

$\mathrm{He}$ is temporary exempted, employed as tutor in civil engineering department, faculty of engineering, Port Said University, Egypt from 9/1/2010 to 13/7/2012. Employed as assistant lecturer in civil engineering department, faculty of engineering, Port Said University, Egypt from $14 / 7 / 2012$ to 22/2/2014.get the mission from the ministry of higher education (MOHE) and from 23/2/2014 to up till now he is a Ph.D. student in Egypt Japanese University of Science and Technology, Borg Al-Arab, Alexandria, Egypt. 